\title{
The reflection of the punishment practice of heterodoxy in the subculture of prisons of the past centuries
}

\author{
Margarita Novak $^{1 *}$, Sergey Borisov ${ }^{2}$, Angelina Goraynova ${ }^{1}$, and Natalia Grigorenko ${ }^{2}$ \\ ${ }^{1}$ Belgorod State Institute of Art and Culture, 308033, Belgorod, Russia \\ ${ }^{2}$ Belgorod National Research University, 308015, Belgorod, Russia
}

\begin{abstract}
The article presents the attitude of prisoners of the past centuries in Russia to punishment, their fate, which they represented in the form of song creation and various metaphorical images. These images have passed through time and are associated with the perception of the prison as a special space. Therefore the authors use already described examples how a prison could look at the end of the Middle Ages.
\end{abstract}

\section{Introduction}

Prison as an enclosed space probably implies the prisoners' struggle with sensory and social deprivation and their attempts to overcome the distressing imprisonment state through creativity. In Russia heterodoxy was punished by imprisonment in monastic prisons. But since in ancient times in such prisons the wards were replaced with pits in earth, the creativity of the prisoners could not be preserved in the form of graffiti as it was in Europe where there were many records and drawings on the walls of former prisons. However the concept of a prison and punishment is well represented in the oral songwriting of Russian prisoners of the nineteenth century. The songs are guessed religious images and metaphors.

\section{Setting a research problem and method}

Our research task was to determine the similarity or difference of prison conditions in past centuries in Russia and Europe (Catholic countries) for prisoners who were punished for their heterodoxy and for this purpose we used the comparison method.

Also we used the semiotic approach to study the metaphorical component of the song creativity of Russian prisoners in the 19th century.

\footnotetext{
* Corresponding author: novakmargarita@yandex.ru
} 


\section{Cases and their analysis}

Comparing the practice of religious dissent punishment in Russian and European cultures, we would like to note that prisons in the Middle Ages can be divided into several types. M.Gazzini writes that from the thirteenth century the prison was a characteristic element of the urban landscape and prisons were divided into state, private and church ones. At first, many prisons were located either in the center of the city or at least within it as the prison was a manifestation of the power. A prison itself was not a closed institution as it is today and prisoners could continue their business or simply beg in the absence of adequate food (Gazzini, 2017, P.29). "The prisons used by the Inquisition could be secret (created for detention) and penitential ones. In the first type of prisons more severe order, physical suffering and darkness reigned but in penitential ones, if a prisoner was ready to repent, his life was much easier and the prisoner's position was like a house arrest. Prisoners were to be kept in absolute isolation to prevent the spread of heretical doctrines. No one was allowed to speak to them excepting the inquisitor and the prison overseer. The Manual of 1561 recommended to take into account the social status of prisoners and the prison regime was more or less severe depending on the crimes" (Dizionario storico dell'Inquisizione, V.1, P.269-270).

A person who has been punished with imprisonment, even being accused of disbelief or distortion of faith, does not lose hope for spiritual salvation and support. In Narni (Terni province, Umbria region (Narni, carcere del Sant'Uffizio)) in the prison of the sacred office prison graffiti has been preserved up to this day (1759): the Sun, the figure of a priest, icons with crosses, etc. In other preserved up to date prisons we can see similar graffiti (in Palermo - Palazzo Steri-Chiaramonte, etc. (Dizionario storico dell'Inquisizione. Inserto iconografico, 2010, P. 41-43). In the practice of scientific research in Italy the theme of prison and monastic graffiti from different time periods has been developed quite widely and from various sides. This can be seen in the works of D.Santarelli, Carceri e iscrizioni spontanee nel castello di Sermoneta, 1999; M.Camaiti Graffiti e pitture murali nelle ex carceri di Palazzo Chiaramonte a Palermo. Studio sui materiali e sulle tecniche, 2005; G.Civale, Animo carcerato. Inquisizione, detenzione e graffiti a Palermo nel secolo XVII, 2017 and many others.

In Russia the history of the punishment of dissenters as we have already mentioned begins with monastic prisons and continues a long history of penal servitude and exile to Siberia, Transbaikalia and the Far East where the assimilation of new territories of the Russian Empire took place. Certainly, this is the main specificity of the practice of punishment in Russia because in Europe they tried to fight against heretical movements in slightly different ways (the spaces of the European powers before large-scale colonization could not favour the spread of such punishment as an exile). M. Foucault, the famous French philosopher, said that capitalist society is represented by the society of confinement, besides he also singled out the society of massacre and ritual killings, the society of exile and the society of rehabilitation (Foucault, 2005, P.10). Nevertheless at the time of the proliferation of monastic prisons in Russia we do not observe the established capitalist system. More exactly the huge territory and climatic conditions were the triggering mechanism that provoked the setting of the exile and the penal servitude as specially practiced types of punishment. In fact, monastic prisons were the forerunner of the exile practice as sometimes they were on the distant or northern borders of Russia. Thus, the prison and the exile in the early history of Russia were practically combined into one type of punishment.

The custody in monastic prisons in Russia differs from the practice of punishment existing in Europe and first of all harsh climatic conditions affect these differences. People who have stepped back from the Orthodox faith, Old Believers or people who are 
unreliable, carrying dangerous ideas or insane from the view point of the church and society were usually sent to such places. The most famous monasteries where such ancient prisons operated were the Suzdal Spaso-Euthymius and the Solovetsky Monasteries. However, the explorer of the past A.S.Prugavin also knows such monasteries as Nikolaevsky Korelsky (Arkhangelsk province), Siya on the Northern Dvina, Spaso-Prilutsky near Vologda, Novgorod-Seversky, Kirillo-Belozersky, Valaam, Spaso-Preobrazhensky in Staraya Russa, Yurievsky near Novgorod, Pskov, Sviyazhsky (Kazan province), Dalmatovsky Assumption (Perm province), Trinity Selenginsky (near Baikal), Voznesensky (Irkutsk province), Assumption Nerchinsky, etc. He also names the female monasteries: Intercession (Pokrovsky) and Rizopolozhensky in the city of Suzdal in Vladimir province, Dalmatovsky Vvedensky (Perm province), Kashinsky (Tver province), Yenisei Nativity, Znamensky (Irkutsk province), etc. (Prugavin, 1905, P.35-36). Monastic prisons also played the role of a political prison since all kinds of rebels and persons dangerous to the rulers of the state were sent there.

Conditions for prisoners in such places were more than harsh. If a prisoner died, they tried to hide his grave especially if it was a significant schismatic or sectarian: his funeral was held in the early morning outside the monastery walls and his grave had no elevation, etc.) (Prugavin, 1905, P.17). Initially there were no specially adapted rooms in the monasteries and monastic cells could be used as wards. Then instead of the usual wards a particularly "dangerous" prisoner was kept in a separate earthen pit. It was forbidden to talk to him, to fulfill his requests, to send messages from him, to give him writing accessories. Afterwards used they no longer earthen pits and prisoners could be kept in ordinary wards. The earthen pit (ward) was a size of $2.1 \mathrm{~m}$ deep (the standard depth of a burial - the authors' note) which edges were covered with bricks and instead of the roof there were wood boards covered with earth on top. There was a hole with a door and a lock in the roof through which it was supposed to serve bread and water. Once a day the vessel used as a toilet was cleaned and the floor was covered with straw. It was unknown whether there was a stove in the spit (it would be difficult to use it - the authors' note). It was possible to visit the church only occasionally (Prugavin, 1905, P.27-28). The winter period did not alleviate the lot of those who were imprisoned there but only aggravated it. Everything was done so that the heresy was buried in the monastery walls and it was not spread but at the same time the person himself who was trying to follow his faith and convictions was also buried (According to A.Prugavin some prisoners spent more than 60 years in such prison since they were supposed to be sentenced to life in a monastery prison). As we can imagine, this was the symbolic meaning of this type of punishment. However, both Italian prisoners who painted religious graffiti on the walls of their dungeons and Russian prisoners did not turn away from their faith and religious images, hoping probably only for their faith. But if medieval Italian graffiti has survived to the present day, then the graffiti of the earthen prisons in Russia could hardly be created and especially survived. That is why we can judge the feelings of prisoners or persecuted persons by their oral or literary works. In Russia a unique monument of Russian literature of the 17th century is "The Life of Avvakum, written by him" that is undoubtedly one of the first well-known autobiographies in Russian. But there is also oral songwriting collected, alas, only in the nineteenth century. However, religious images familiar to the Orthodox consciousness were hidden even in the songs of prisoners of the nineteenth century despite the fact that prisoners were no longer kept in the harsh conditions of an earthen prison. We would like to pay attention to the fact that a number of songs collected by researchers of musical folklore contain barely guessed archetypal images of Hell and paradise which may serve as an indirect sign that the songs initially referred to the monastery prisons - a combination of something infernal, "underground" and something sacred, "heavenly". 
So, in some songs the prison interpreted as a certain space different sharply from the usual life is perceived as an infernal place which is located underground and associated with anguish. There is also an indication for any locks (iron objects) that can be associated with superstitions related to blacksmithing not quite "clean" and opposed to all sacred things because a blacksmith like the devil "deals" with fire and can deceive people making low-quality items. We would like to note that in the description of the hell there are such characteristics as "eternal fire" and "external darkness".

Example 1: One of the songs mentions a prisoner Vanya who is serving a sentence in Moscow in a stone earthen prison "behind prison bars, behind iron doors, behind padlocks". (Maksimov, 2012, P.109).

Example 2: Another song also describes how a prisoner of a stone (earthen) prison is monting the scaffold to be hanged. (Maksimov, 2012, P.110).

Example 3: One more song depicts the formidable wardens guarding a strong earthen prison which it is impossible to get out of but a terrible cloud can break it (the prison). (Maksimov, 2012, P.111). (The cloud here has in mind the sky that on its part means higher forces which intervention is a condition of salvation from the prison - authors' note).

In Russian culture there is also a direct association of a prison and punishment with hellish space. The word "hell" is derived from the Greek "ко $\lambda \alpha \sigma \varepsilon$ " (torment) and can be understood as "trimming the branches of a tree" or as "punishing". At the same time a person punishes himself as he allows a rupture with God. (In the case of imprisonment there is a rupture with the family - authors' note). Orthodoxy affirms that the deepest meaning of human existence is his creation in the image of God (Orthodoxy and the world - electronic resource). The Orthodox understanding of punishment correlates with the situation of punishment for one's own fault by being removed from the worldly life breaking with it and falling into a strictly harsh environment and difficult survival conditions. It is not easy to be released from prison; sometimes it is impossible to return to ordinary worldly life. The liberation from the torments of hell is possible but only after the Last Judgment and this hope is also illusory since the possibility of liberation is infinitely far and is not defined in the time aspect. Hence allusions and images are born in the works of prisoners.

Probably the prison is perceived precisely as a space similar to a sacred place because the first prisons were set up in the monasteries of Russia. Thus, obtaining (sometimes new) spiritual experience was associated with the incarceration. Subsequently the prisons organized outside the monastery were still similar to the monastic prisons because they reproduced the experience of complete rupturing with the worldly life, living "not in the secular world" and in fact not among people and more over represented an analogue of "afterlife" existence without the right to "return back". Going to prison, the identity of the person seemed to be dying and being born anew. This was facilitated by the prison's multiple rituals: the appearance of nick-names instead of names, changing clothes, cutting hair, washing, etc. The presence of walls, locks and keys caused associations with the place taken beyond any limits where none can penetrate into. Like a monk in the monastery a prisoner had the opportunity to renounce his past, meditate and devote his time to thoughts about God and sometimes to useful work. Although the model of a modern penitentiary institution restricts freedom but it does not at all imply breaking ties with society (prisoners have the opportunity to use the mass media), family and many old habits. Hence the huge problem of transmission and dissemination of criminal experience appears in the cells of modern penitentiaries.

We have already indicated in this article that in some folk art there are images of locks and keys. Initially, keys in Christian culture are an attribute of Apostle Peter the guardian of paradise. The key seems to unlock bliss, peace and grace. Prisoners associate a key with freedom, so they often use the key image in prison songs similar to the Christian image of 
the key to paradise. The final punishment or the use of locks and keys can be a desired act in these songs as it stops the torment of imprisonment.

Example 1: In one of the songs a prisoner asks his family (his wife and mum) to take the golden keys, unlock the twisted locks, put on best clothes and go to the officials with the request to release him (Maksimov, 2012, P.102).

Example 2: The following song describes a warden who carries large keys in his hands. Then he opens the prison doors and leads the prisoners (in the song, they are meant as kind, good and young people) to inflict a punishment, probably a death penalty (Maksimov, 2012, P.131-132). In this case the punishment is perceived as deliverance.

Images of animals are used in prison songs and most often a bird because the bird is a free creature and not imprisoned like an animal in a forest or in a city like a man. For example, in the song recorded by V.N. Garteveld "Among the Stone Chambers" (Akatuevskaya penal servitude) the pitiful image of the lark is mentioned. According to G.V. Kosyakov, the lark was associated with the immortal soul at least among the Russian romantics. The author writes that the bird image symbolized naturalness, freedom, proximity to the High World and paradise and was oppositional to a human being "inside whom a royal ontological status contrasts with sinfulness" (Kosyakov, 2007, P.24-27). The lark could not be only associated with a herald of the spring but also be a symbol of the Higher World. Thus in the prisoners' work we find a rather highly poetic and sublime metaphor.

\section{Conclusion}

These examples lead us to the idea that a prison that is perceived as a place of acquiring special life and spiritual experience which makes a person different i.d. restores him either "to the light" or "to the darkness" and combines the characteristics of both celestial and infernal spaces. So, the keys in Christian culture are more associated with the image of paradise but in prison creativity they mean deliverance from imprisonment even if at the cost of living. At the same time being in the prison distinguishes suffering for criminal cases that corresponds to the notion of hell.

\section{References}

1. M. Gazzini, Storie di vita e di malavita. Criminali, poveri e altri miserabili nelle carceri di Milano alla fine del Medioevo (Firenze University Press, Firenze, 2017) (In Italian)

2. Dizionario storico dell'Inquisizione, diretto da A.Prosperi. Pisa: Edizioni Della Normale. (Scuola Normale Superiore Pisa), 1, (2010) (In Italian)

3. Dizionario storico dell'Inquisizione. Inserto iconografico, diretto da A.Prosperi. Pisa: Edizioni Della Normale. (Scuola Normale Superiore Pisa), (2010) (In Italian)

4. G. Civale, «Animo carcerato. Inquisizione, detenzione e graffiti a Palermo nel secolo XVII.», Mediterranea - ricerche storiche, 40, 249-294 (2017) (In Italian)

5. Orthodoxy and the world. Information on https://www.pravmir.ru/ad/ (In Russian)

6. G.V. Kosyakov, "Mythopoetics of the Image of the Winged Soul in Russian Romantic Poetry", Tomsk State University Bulletin, 294, 24-27 (2007) (In Russian)

7. S.V. Maksimov, "Prison Songs" Songs of penal servitude. Collection of V.N.Garteveld with the application of essays on penal servitude and prison songs and poetry by S.V. Maksimov, N. M. Yadrintsev, V. M. Doroshevich. Salamandra P.V.V., (2012) (In Russian) 
8. A.S. Prugavin, Monastic prisons in the fight against sectarianism (revisited religious tolerance), (Mediator, Moscow, 1905) (In Russian)

9. M. Foucault, Intellectuals and Power: Selected political articles, speeches and interviews, Part 2, (Praxis, Moscow, 2005) . (In Russian) 